\title{
Socio-emotional Dimensions in Gifted Chilean High School Students with Interests in STEM: Influence of Gender and University Enrichment Program Participation
}

\author{
María P. Gómez-Arízaga ${ }^{1}$, Marianela Navarro ${ }^{1 *}$, Annjeannette Martin ${ }^{1}$, Karin Roa-Tampe ${ }^{1}$, \\ María Leonor Conejeros-Solar ${ }^{2}$, Leonie Kronborg ${ }^{3}$, Marieta Valdivia-Lefort ${ }^{4}$, \\ Hernán Castillo-Hermosilla ${ }^{5}$, Bárbara Rivera-Lino ${ }^{1}$ \\ ${ }^{1}$ Facultad de Educación, Universidad de los Andes, CHILE \\ 2 Escuela de Pedagogía, Pontificia Universidad Católica de Valparaíso, CHILE \\ ${ }^{3}$ Faculty of Education, Monash University, AUSTRALIA \\ ${ }^{4}$ Institute of the Americas, University College London, UNITED KINGDOM \\ ${ }^{5}$ Universidad Mayor, CHILE
}

Received 19 August 2020 - Accepted 11 November 2020

\begin{abstract}
This article contributes to the study of the gender gap for women in STEM, by exploring the socioemotional dimensions of gifted girls with positive attitudes toward math and science, as measured by the TOSRA and TOMRA. The variables of self-concept, self-efficacy, and gender stereotype identification were examined, using the Piers-Harris Self-Concept Scale, Sources of Science and Mathematics Self-Efficacy Scale, and Masculine-Feminine Inventory, based on gender and extracurricular enrichment program participation. The sample consisted of 103 Chilean students in $10^{\text {th }}$ grade, identified as gifted using the Raven's Standard Progressive Matrices. Data were analyzed using Multivariate Analysis of Variance (MANOVA), Analysis of Variance (ANOVA), and t-tests to analyze the effects of gender and enrichment program participation. Results showed that self-concept for girls is lower than for boys, and lower for girls who attended enrichment programs, compared to girls who did not attend programs. Furthermore, an interaction effect was observed between gender and enrichment program attendance on the gender stereotype subscales of masculinity and submission. Implications for enrichment programs were discussed, suggesting the need to (a) focus on girls' self-concept, (b) decrease the risk of stereotype threat, and (c) encourage gifted girls to identify how they experience and act upon gender stereotypes.
\end{abstract}

Keywords: gender stereotypes, gifted females, gifted programs, self-concept, STEM

\section{INTRODUCTION}

Although Science, Technology, Engineering, and Mathematics (STEM) skills are considered a 21st century necessity for future economic and technological innovation and development (Hutchinson, 2013), studies have shown that women are far less represented than men in STEM careers. The process through which this gap is produced, begins and intensifies during the K-12 schooling period when girls and women display a decreasing interest in these areas in comparison to their male peers (Organisation for Economic Co-operation and Development [OECD], 2015). For this research, STEM is understood as "an acronym for the disciplines of science, technology, engineering and mathematics taught and applied either in a traditional and disciplinespecific manner or through a multidisciplinary, interconnected and integrative approach" (Siekmann, 2016, p. 3). Particularly, this study focuses on the specific disciplines of science and mathematics because they are obligatory, core subjects in the Chilean national K-12 curriculum, along with Spanish Language Arts. Other

(c) 2020 by the authors; licensee Modestum. This article is an open access article distributed under the terms and conditions of the Creative Commons Attribution License (http://creativecommons.org/licenses/by/4.0/). 


\section{Contribution to the literature}

- Although attitudes towards STEM is a topic that has been investigated, this study focuses on gifted students with positive attitudes in STEM, revealing gender differences in socio-emotional dimensions in this population, such as self-concept.

- This study contributes to the existing literature by showing how female students with high interest in STEM areas, particularly those who participate in enrichment programs, are most affected by negative gender personality traits.

- The study presents results of the Big Fish Little Pond Effect in Latin America's gifted population with a special focus on male and female students who have participated in enrichment programs.

subject matters are defined as peripheral (Osandón et al., 2018).

In Chile, there is ample evidence of this gender gap, in national and international assessments. For example, in the Programme for International Student Assessment (PISA), Chile is ranked as the third country with the most significant gap between 15-year-old boys and girls in mathematics and 11th in science, favoring boys in both cases (OECD, 2014).

Additional evidence can be found in undergraduate enrolments in STEM-related fields: women in Chile tend to enroll more frequently in careers typically considered "feminine," such as health or education (78\% females) and less so in fields that are traditionally considered "masculine," such as engineering or science $(18 \%$ females) (Comisión Nacional de Investigación Científica y Tecnológica [CONICYT], 2015). The cause of this gap appears not to be rooted in cognitive abilities, but in social cognitive factors. In particular, self-concept and self-efficacy have been found to be strong predictors associated with mathematics and science achievement and help to explain the gender differences found in these fields (Lee \& Kung, 2017; Recber et al., 2018; WebbWilliams, 2017).

Similar trends can be seen in studies related to career decision-making and self-perceptions of gifted boys and girls in science and mathematics. Although results have consistently shown that these two groups have similar abilities and intelligence (Kerr et al., 2012), gifted girls (a) do not show the same interest in pursuing STEM fields as boys (Camci-Erdogan \& Riga, 2016; Heilbronner, 2013); (b) enroll less in courses such as physics (Zohar \& Sela, 2003); and (c) demonstrate more ambivalence towards competitive conditions (Dai, 2002). Gifted girls tend to be more affected also, by the Big Fish Little Pond Effect (BFLPE), which refers to the social comparisons made by students when they participate in educational settings with students of similar abilities (Parker et al., 2014), where negative effects for self-concept were found to be larger for girls than boys (Plieninger \& Dickhäuser, 2015).

Many of these differences can be attributed to social behaviors and beliefs deeply rooted in the upbringing and education of both sexes that can shape the way they perceive themselves, and the choices they make. For instance, even when both gifted boys and girls display math and science abilities during their early years, when they enter the period of adolescence, results have found that gifted girls are more likely to hide those abilities because they are considered less "feminine" or "attractive" by their peers (Kerr \& Multon, 2015).

In this study, we aim to contribute to the discussion of the gender gap for gifted girls, both those who participate in university-based enrichment programs (UBEP) and those who do not, and by focusing on those gifted girls who demonstrate positive interests toward mathematics and/or science. Additionally, as stated before, several socioemotional constructs that have been strongly associated with explaining the gender gap between males and females in STEM were examined: self-concept, self-efficacy, and gender stereotype identification.

\section{THEORETICAL FRAMEWORK}

\section{The Concept of Giftedness}

In educational contexts, giftedness can be defined as students with "gifts and talents who perform or have the capability to perform at higher levels compared to others of the same age, experience, and environment in one or more domains" (National Association for Gifted Children [NAGC], 2020). The conceptualization of giftedness was originally associated with the concept of intelligence (Conejeros-Solar et al., 2012); however, a more sociocultural understanding of giftedness and its manifestations has evolved that takes into account contextual variables and non-cognitive attributes, in addition to high potential (Kaufman \& Sternberg, 2008). In Gagné's (2015) Differentiated Model of Giftedness and Talent (DMGT), the most widely used model in Chile and the model on which this research is based, Gagné mentions that the origins of the development of giftedness can be found in the progressive accumulation of natural capacities that are influenced by different factors: these include family support and the educational system, which are environmental catalysts, and factors such as intrinsic motivation and perseverance which act as intrapersonal catalysts for the development of students' potential. 


\section{Female Giftedness}

Regarding potential, gifted girls have been found to display characteristics that make them more like their gifted male peers (Kerr et al., 2012). However, the development of talent in females is not as straightforward as in males. At the high school level, young gifted females tend to earn high grades and participate in multiple extracurricular activities, yet they enroll less in challenging STEM courses (Kerr, 2009). At this stage, intellectual abilities and curiosity can be intertwined with low self-confidence, which may put gifted girls at risk of avoiding non-traditional career paths. Also, as they move through adolescence, gifted girls might hold more traditional female roles and beliefs regarding career choice (Fiebig, 2008).

\section{LITERATURE REVIEW}

\section{Attitudes and Interests toward STEM-related Disciplines}

Student attitudes can significantly influence the decisions about university enrollment and career choice (OECD, 2008). Studies have found that gender is the factor with the most explanatory power in explaining student attitudes toward science (Valenti et al., 2016). Studies in different cultures have shown that girls feel less prepared and more anxious than boys toward science and mathematics as early as 8 th grade and have often abandoned their interest in these areas by this age (Agencia Calidad de la Educación, 2015; Microsoft Foundation, 2016).

There is little evidence regarding gifted students' attitudes toward STEM-related disciplines, particularly gifted girls, given that most of these studies have been conducted in mainstream classrooms (Gubbels et al., 2014). Peer and Fraser (2015), however, using the Test of Science Related Attitudes (TOSRA), did find that gifted girls scored lower on enjoyment of science than gifted boys, but also had slightly lower scores than their nongifted female counterparts.

\section{Self-concept and Self-efficacy}

\section{Self-concept}

Self-concept can be understood, in a general sense, as the evaluation of oneself (Plieninger \& Dickhäuser, 2015); academically speaking, it is the way a student perceives him or herself in the context of internal and external comparisons (Parker et al., 2014). The relationship between self-concept and academic performance in adolescence has been contrasted and confirmed in several studies: higher levels of selfconcept are associated with greater time investment in learning and greater willingness to engage in learningrelated experiences, which improves educational results (Hattie, 2009; Huang, 2011; Vera et al., 2019). Academic achievement in a specific domain, in turn, increases the probability of having a good disposition towards the area of specific learning and the decision making process in applying for related careers, hence, the connection to gender gaps in STEM area careers (Eccles, 2013; Reilly et al., 2019).

The evidence indicates that self-concept tends to diminish in late childhood (8 to 11 years) and decreases again in early adolescence before improving in later stages. Regarding gifted students, gifted girls display the greatest decline in self-concept, self-confidence, and selfperceived abilities during high school (Colangelo \& Assouline, 1995; Rudasill et al., 2009). Similarly, Preckel, Goetz, et al. (2008) found that gifted girls' academic selfconcept was more similar to their average-ability counterparts than to gifted boys and that both groups of girls had lower interest towards mathematics than boys.

Regarding self-concept differences between boys and girls in highly competitive environments, the evidence points to the Big Fish Little Pond Effect (BFLPE). Preckel, Zeidner, et al. (2008) found that gifted female students had lower self-concepts, particularly affected by the male/female ratio. Similarly, Plieninger and Dickhäuser (2015), studied the moderator effect of gender on the BFLPE and found a substantial difference, favoring male over female students in Germany.

In the Chilean context, in a study conducted with male and female gifted adolescents, Roa-Tampe et al. (2020) found that female students who participated in competitive environments, such as university-based gifted programs, showed a lower self-concept than their male counterparts and identified with stereotypical traits associated with submission, such as indecision and dependence.

\section{Self-efficacy}

Although self-efficacy shares the self-evaluative nature of self-concept, it is related to the judgment students make about their confidence in their personal abilities (Bandura, 1997); however, it varies depending on the domain and the context, which means it can fluctuate greatly (Schunk \& DiBenedetto, 2016). Studies have provided evidence, particularly in girls, that there is an important decline in self-efficacy around fifth grade, mainly in mathematics (Greenlee, 2016). However, different results have been found in secondary students, such as the study conducted by Ayotola and Adedeji (2009) that found no significant differences between male and female mathematics self-efficacy and achievement.

Regarding gifted females, the evidence on selfefficacy is not always consistent. In a study related to the potential for gifted women to enter a STEM career, Kerr and Kurpius (2004) predicted low probability for choosing these fields because high aspirations were combined with low self-efficacy, and high intellectual 
curiosity with a desire for conformity. Additionally, Kerr and McKay (2014) maintain that self-efficacy may decrease in girls in high school, although gifted women continue to be high achievers. However, other studies have shown that there were no gender differences in the self-efficacy reported among gifted students, both at undergraduate and school levels (Al-alusi, 2001; AlDhaimat et al., 2020; Turki \& Al-Qaisi, 2012).

Regarding special provisions for gifted students, a study conducted with accelerated secondary students found no significant differences in mathematics selfefficacy between males and females (Probst, 2019). Yet, in the case of special schools for gifted students, a study conducted by Neber and Schommer (2002) found that girls in these schools displayed lower science selfefficacy than boys. In regards to enrichment programs, it has been found that they can have a positive effect on girls, enhancing their self-efficacy (Young et al., 2019).

\section{Gender and Gender Stereotypes}

The category of gender encompasses behavior and attributes that are constructed predominantly, though not exclusively, by being men and women within a certain culture. These attributes or traits reflect shared images and practices that are progressively internalized by individuals through socialization and then renewed daily in social life. The configuration of beliefs around these traits, regarding both their most desirable and their most negative aspects, leads to the gradual formation of gender stereotypes.

Gender stereotypes define generalized expectations for men and women, in terms of behavior and characteristics, that are learned, internalized, and then reinforced in daily social interactions (Kollmayer et al., 2016). In contrast with other stereotypes, gender stereotypes are presented as polar opposites and tend to characterize men and women as pure types with specific attributes. Hence, there is a tendency, for example, to emphasize and reward in traditional cultures, women's expressiveness, emotionality, passivity, and warmth, with little nuance, and to likewise highlight instrumentality, rationality, initiative, and productivity in men (Ellemers, 2018). In this sense, the notion of stereotype stresses the negative aspects of a rigid and fixed characterization that does not adequately represent individual cases; in spite of this, its cultural hold is confirmed by way of social sanction for behaviors that do not adjust to social expectation, also called counterstereotypical behaviors (Ellemers, 2018).

The cultural reproduction of these stereotypical traits occurs from the very beginning of social life through upbringing and education. Gender stereotypes establish expected behaviors early on; boys and girls then gradually respond to the ways of being that are defined as culturally appropriate for each gender, which produces behavioral differences that intensify as they grow older (Kollmayer et al., 2016).

The stereotypical traits that hold girls back in STEM are acquired as early as first grade (Boston \& Cimpian, 2018) and tend to persist over time (Nagy et al., 2010). Gender-based stereotypes associating masculinity with mathematics and science and femininity with the humanities is a pattern that tends to hold true across diverse cultural contexts (Charles, 2017; Deemer et al., 2014; Kerr \& Multon, 2015; Miller et al., 2015), and seems to be particularly strong in Latin America (Scantebury \& Baker, 2007). A study conducted in Chile found that boys and girls from mid-low socio-economic status (SES) associate math with masculinity, whereas girls from high SES do not associate math with either gender. These findings are evidence for the influence of SES in stereotypes regarding math; therefore, stereotypes constitute a factor in the gender gap related to math achievement (Del Río et al., 2016).

However, in the academically gifted student population, some studies show that female adolescents tend to form less traditional gender identities. Hence, they display greater indifference towards attributes like popularity when compared with their non-gifted female peers. Additionally, they tend to prefer classes with more masculine presence, agree with instrumental attributes typically associated with masculinity, show higher career aspirations, and subsequently occupy leadership positions in their future workplaces (Fiebig \& Beauregard, 2011; Kao, 2015). However, these characteristics tend to vary throughout girls' adolescence and by cultural context: for example, professional aspirations and instrumentality attributes increase in Germany, but decrease in the United States, as gifted adolescent girls get older (Fiebig \& Beauregard, 2011).

It has also been found that gifted female students are conscious of sexism and exhibit rejection of the lower status given to women in society (Kao, 2015; Kerr \& Multon, 2015; Maso \& Proestakis, 2007). In a study conducted in Taiwan, adolescents displayed a greater willingness to agree with negative feminine stereotypes that associated women with characteristics such as exclusion, closed-mindedness, criticism, competition, and envy of others (Kao, 2015).

Regarding preferences for mathematics and science, gifted women present higher vulnerability to stereotype threat, understood as the concern that individuals experience when they perceive themselves to be at risk of confirming a negative stereotype (Deemer et al., 2014; Steele, 1997). Hence, they adhere to traditional gender stereotypes, abandoning their preference for STEM areas (Kerr et al., 2012). 


\section{UBEPs in Chile}

The first university-based enrichment programs (UBEP) were created in Chile in 2001 with the goal of providing enrichment opportunities for gifted students who come mostly from public schools, who do not have opportunities to develop and nurture their potential giftedness due to their socioeconomic status (ConejerosSolar, 2012; Gómez-Arízaga et al., 2020). Currently, seven UBEPs, based on the principles of Gagne's Model (Gagné, 2015), exist in different regions of Chile and serve students between 6 th and 12th grades. The curriculum implemented in these programs aims to provide courses and workshops that are taught by university professors or teachers with expertise in a specific discipline (López et al., 2013). Each semester, students choose two courses and one workshop of interest among a wide array of options: STEM courses, Language Arts, History, Philosophy, among others.

To enter one of these programs, public schools are invited to nominate students in the aforementioned grades based on a locally designed nomination instrument that identifies highly able students in different subject/talent domains compared to their chronological aged peers. Afterwards, the nominated students are administered the Raven Standard Progressive Matrices Test. Using local norms, approximately $10 \%$ of the nominated students are selected to become part of a UBEP (Gómez-Arízaga \& Conejeros-Solar, 2013).

Focusing primarily on gifted girls, the purpose of this research was to analyze the differences in socioemotional dimensions (self-concept, self-efficacy, and gender stereotypes) of Chilean 10th grade gifted students with positive attitudes toward science and/or mathematics, considering gender and UBEP participation. The research question that guided the investigation was the following:

What is the influence of gender and enrichment program participation on socio-emotional dimensions and gender stereotypes of gifted high school students with positive attitudes toward mathematics and/or science?

\section{METHODS}

\section{Participants}

The sampling was carried out in two stages: in the first stage, 10th grade students, from two UBEPs and seven high schools were invited to participate. One of the programs is located in the central zone of Chile and the other in a southern region; whereas the high schools are all located in the Metropolitan Region. The high schools were chosen to represent high, medium, and low socio-economic groups, whereas the students from the UBEPs are predominantly from lower socio-economic groups. Although the study focuses on girls, both males and females were invited to participate in order to gain insight into the influence of gender through adequate comparison with their male peers.

During visits to each institution, all 10th grade students were personally invited to participate; they were provided with a description of the study, its purposes, and an explanation of what participation entailed. At the two UBEPs, 52 10th grade students agreed to participate. These students had already been identified as gifted as part of the selection process to attend the program, and had been evaluated using the Raven's Progressive Matrices (Raven et al., 1993), a general scale of visual-spatial ability. This test was established by Chile's Ministry of Education, by way of decree No. 230 and its corresponding modification, decree No. 341, for use by higher education institutions that provide enrichment programs to identify gifted students (Ministry of Education, 2010).

From the seven high schools, 260 students volunteered to participate, constituting a $70-80 \%$ acceptance rate, depending on the school. To identify potentially gifted students, following the protocol established by the Ministry of Education (2010), the Raven's Progressive Matrices was administered. For this study, the 90th percentile was established as the cut-off point, based on Gagnés prevalence of giftedness or talent $(2015,2018)$, which he argues is $10 \%$ of the population. Of the 260 students who agreed to participate, 124 scored at or above the 90th percentile and passed to the second stage. Although this number constituted almost $50 \%$ of the initial sample, this could be due to self-selection in agreeing to participate in the study. Along with these 124 high school students, 52 UBEP participants were invited to pass to the second stage of identification, of whom 102 agreed to continue; hence, the final sample at the end of the first stage was 154.

The second stage identified students with favorable attitudes towards math and/or science, using instruments that measured attitudes toward science (TOSRA) and toward mathematics (TOMRA). Given that the TOSRA and TOMRA are 5-point Likert scales used to carry out this selection, a cut-off rate of 3.5 was established for the results obtained by students on these instruments. A score of 3.5 or higher indicated a favorable attitude towards science or math, respectively.

Therefore, the final sample was composed of 103 gifted students with positive attitudes toward mathematics and/or science in the second year of high school. Of these participants, 41 attended one of the two UBEPs and 62 attended one of the participating high schools. For more details regarding gender and socioeconomic distribution, see Table 1. 
Table 1. Participant sampling stages

\begin{tabular}{|c|c|c|c|c|c|c|c|c|c|}
\hline & \multirow[t]{3}{*}{ SES } & \multicolumn{4}{|c|}{$\begin{array}{l}\text { First stage of sampling } \\
\text { (Gifted students) }\end{array}$} & \multicolumn{4}{|c|}{$\begin{array}{c}\text { Second stage of sampling } \\
\text { (Gifted students + Favorable attitudes towards } \\
\text { math and/or science) }\end{array}$} \\
\hline & & \multicolumn{2}{|c|}{ Boys } & \multicolumn{2}{|c|}{ Girls } & \multicolumn{2}{|c|}{ Boys } & \multicolumn{2}{|c|}{ Girls } \\
\hline & & $\mathrm{N}$ & $\%$ & $\mathrm{~N}$ & $\%$ & $\mathrm{~N}$ & $\%$ & $\mathrm{~N}$ & $\%$ \\
\hline \multirow{3}{*}{ School } & Low & 21 & 14 & 14 & 9 & 12 & 12 & 9 & 9 \\
\hline & Mid & 19 & 12 & 16 & 10 & 9 & 9 & 10 & 10 \\
\hline & High & 17 & 11 & 15 & 10 & 13 & 13 & 9 & 9 \\
\hline Subtotal & & 57 & 37 & 45 & 29 & 34 & 33 & 28 & 27 \\
\hline Program & & 23 & 15 & 29 & 19 & 24 & 23 & 17 & 17 \\
\hline Total & & 80 & 52 & 74 & 48 & 58 & 56 & 45 & 44 \\
\hline
\end{tabular}

\section{Instruments}

\section{Raven's standard progressive matrices}

Raven's Standard Progressive Matrices is a nonverbal instrument that measures basic cognitive functioning by means of a visual approach; it is a measure of fluid intelligence and shows no gender differences (Mackintosh \& Bennett, 2005). It has a reliability coefficient range between 0.76 and 0.91 (Conejeros-Solar \& Gómez-Arízaga, 2015). It is used to identify giftedness in Chile by university-based programs, as stated by the Ministry of Education (MINEDUC, 2011).

\section{Instruments to measure attitudes towards science and mathematics}

The Test of Science Related Attitudes (TOSRA) (Fraser, 1981) was used. It is a specific version of the test adapted and validated for Chile (Cronbach $a=.80$; $\mathrm{X}^{2}=8363.68$; GFI $=.64$; $\mathrm{RMSEA}=.06$; SRMR $=.19$ ) (Navarro et al., 2016). The Test of Mathematics Related Attitudes (TOMRA) adapted by Ogbuehi and Fraser (2007) was used also (Cronbach $\mathrm{a}=.88$ ). Both instruments consist of items on a 5-point Likert scale, where 5 represents strongly agree, 1 represents strongly disagree and 3 represents "neither agree nor disagree", hence, participants with an average score of 3.5 or above were considered to have positive attitudes.

\section{Instruments to measure science and mathematics self- efficacy}

The Sources of Mathematics Self-Efficacy Scale (Usher \& Pajares, 2009) was used. This version was specifically validated for Latin America (Zalazar et al., 2011). Additionally, a modified version of this instrument was used for assessing self-efficacy in science. The Sources of Science and Mathematics SelfEfficacy Scale has good reliability indices (Cronbach $a=.86$ ) (Usher \& Pajares, 2009).

\section{Instrument to measure self-concept}

The Chilean adaptation of the Piers-Harris SelfConcept Scale was used to assess the participants' self- concept (Villarroel, 2001). Test subscales deemed suitable for the gifted population (Lewis \& Knight, 2000) were considered separately for this study.

\section{Instrument to measure gender-related personality characteristics}

The Masculine-Feminine Inventory (IMAFE) is an instrument that measures the identification of individuals with stereotyped masculine and feminine personality traits present in Latin American culture, including both positive and negative characteristics attributed to gender. Created in Mexico in 1993, the instrument asks participants the extent to which they identify with certain characteristics typically associated with each gender. It consists of four subscales, two of which refer to positive attributes associated with each gender (masculinity and femininity), and two of which are defined by negative attributes (machismo and submission) (Martínez-Gómez et al., 2012).

Masculinity refers to positive masculine characteristics related to proactivity and actionorientedness. It contains items such as feeling "Assured" or "I make decisions easily." Machismo, on the other hand, considers negative masculine attributes, such as aggression, domination, and rigidity, in addition to other items such as "authoritative" and "arrogant."

In relation to feminine gender, femininity encompasses characteristics associated with interpersonal abilities and expressiveness, using items such as "sweet," "understanding," and "compassionate," in contrast to the perspective of submission, which refers to feminine traits considered negative, such as weakness and subordination, exemplified by items such as "easily influenced" and "unsure of myself."

Each of these four subscales has 15 items (adjectives or descriptive phrases) that are answered on a scale of 1 to 7, 1 being "I am never or almost never like this" and 7 being "I am always or almost always like this". The instrument has adequate levels of reliability (between .76 and .88 for the subscales) and discriminant validity (Martínez-Gómez et al., 2012). 
Table 2. Descriptive statistics for socio-emotional factors and gender stereotypes by gender and enrichment program attendance

\begin{tabular}{|c|c|c|c|c|c|c|c|c|}
\hline & \multicolumn{4}{|c|}{ Girls } & \multicolumn{4}{|c|}{ Boys } \\
\hline & \multicolumn{2}{|c|}{$\begin{array}{c}\text { Attends gifted } \\
\text { program }(n=24)\end{array}$} & \multicolumn{2}{|c|}{$\begin{array}{l}\text { Does not attend gifted } \\
\text { program }(n=19)\end{array}$} & \multicolumn{2}{|c|}{$\begin{array}{l}\text { Attends gifted } \\
\text { program }(\mathrm{n}=15)\end{array}$} & \multicolumn{2}{|c|}{$\begin{array}{c}\text { Does not attend gifted } \\
\text { program }(\mathrm{n}=28)\end{array}$} \\
\hline & $\mathrm{M}$ & SD & $\mathrm{M}$ & SD & $\mathrm{M}$ & SD & $\mathrm{M}$ & SD \\
\hline Science Self-Efficacy & 3.833 & 0.603 & 3.885 & 0.457 & 3.808 & 0.609 & 3.773 & 0.499 \\
\hline Mathematics Self-Efficacy & 3.767 & 0.838 & 3.754 & 0.811 & 3.962 & 0.638 & 3.800 & 0.645 \\
\hline Self-Concept & 0.668 & 0.169 & 0.780 & 0.144 & 0.789 & 0.111 & 0.801 & 0.105 \\
\hline Masculinity & 4.444 & 0.735 & 5.052 & 0.965 & 4.996 & 0.658 & 4.855 & 0.525 \\
\hline Femininity & 4.763 & 1.181 & 5.065 & 1.115 & 4.622 & 0.736 & 4.591 & 0.963 \\
\hline Machismo & 3.109 & 0.779 & 3.149 & 0.711 & 3.134 & 0.544 & 3.467 & 0.643 \\
\hline Submission & 3.400 & 0.723 & 2.951 & 0.838 & 2.938 & 0.724 & 3.210 & 0.820 \\
\hline
\end{tabular}

\section{Data Analysis}

Descriptive Analysis. First, descriptive analyses were carried out, such as calculating means and standard deviations for the dependent variables according to the independent variables, gender and UBEP attendance.

Inferential Analysis. Three types of inferential statistical analyses were conducted: 1) Multivariate Analysis of Variance (MANOVA) 2) Analysis of Variance (ANOVA) and 3) t-tests. The MANOVA is a multivariate analytic procedure to determine differences between the means of multiple variables: gender and UBEP involvement (independent variables), by means of a joint comparison of the dependent variables measured: self-concept, self-efficacy in science, self-efficacy in mathematics, femininity, masculinity, submission, and machismo. This procedure is used to measure the possible interaction effects of the independent variables on the dependent variables. Next, ANOVA tests were conducted to analyze the specific effect of the independent variables on each of the dependent variables and to check for possible interaction effects. Finally, t-tests were conducted to compare socioemotional dimensions and gender stereotypes between girls who were participating in UBEPs and those who were not, and between boys who were participating in UBEPs and those who were not.

Assumption Contrasts. The assumptions of homogeneity of covariance matrices and homogeneity of variance were tested using Box's M test and Levene's test, respectively. Given that the assumption of homogeneity of covariance matrices was statistically significant, (Box's $M=224.12, F(135)=1.30, p=.012$ ) for the MANOVA, Pillai's Trace was used, which is more robust for assumption violations (Finch, 2005; Olson, 1979). Regarding the result of the Levene's test, it was not significant for any of the dependent variables analyzed, fulfilling the homogeneity of variance assumption required for the ANOVA tests: self-concept $(F(3,82)=1.90, p=.136)$, self-efficacy in science $(F(3,82)$ $=1.16, p=.329)$, self-efficacy in mathematics $(F(3,82)=$ $1.17, p=.327)$, femininity $(F(3,82)=2.19, p=.096)$, masculinity $(F(3,82)=3.89, p=.056)$, submission $(F(3$,
$82)=.49, p=.690)$, and machismo $(F(3,82)=1.24, p=$ $.301)$.

To judge the significance of all statistical tests, a value of $p<0.05$ was used. All analyses were performed with SPSS version 21 .

\section{Ethical Considerations}

Student participation was voluntary and both students and parents signed informed assent and consent forms, respectively. Additionally, this research project was submitted for review and approved by the ethics committee of the affiliated research institution.

\section{RESULTS}

\section{Descriptive Results}

Table 2 shows the means and standard deviations for the dependent variables (science self-efficacy, mathematics self-efficacy, self-concept, masculinity, femininity, machismo and submission) according to the independent variables, gender and UBEP attendance. In this regard, differences are observed: for example, the means of self-efficacy in mathematics and in self-concept are higher for males than for females; these differences were later tested to determine if they were significant.

\section{The Effect of Gender and UBEP Participation on Grouped Socioemotional Dimensions}

The MANOVA results (Table 3), using the Pillai's trace test, show a statistically significant effect for gender on grouped socioemotional dimensions (dependent variables) and a non-significant effect of UBEP attendance on the same variables. There was no statistically significant interaction between the two independent variables on the dependent variables. 
Table 3. MANOVA multivariate effect of gender and enrichment program attendance on the socio-emotional factors

\begin{tabular}{lccccc}
\hline Effect & Pillai's trace & $\mathrm{df}$ & $\mathrm{df}_{\text {error }}$ & $F$ & $p$ \\
Gender & .240 & 9 & 74 & 2.590 & .012 \\
Enrichment Program Attendance & .124 & 9 & 74 & 1.165 & .330 \\
Gender x Enrichment Program Attendance & .137 & 9 & 74 & 1.306 & .124 \\
\hline
\end{tabular}

Table 4. ANOVA univariate effect of gender and enrichment program attendance on each individual dependent variable

\begin{tabular}{|c|c|c|c|c|c|c|}
\hline \multirow{2}{*}{ Effect } & \multirow{2}{*}{ Dependent variable } & \multicolumn{4}{|c|}{ ANOVA } & \multirow[t]{2}{*}{ Significant group differences } \\
\hline & & $\mathrm{df}$ & $\mathrm{F}$ & $\mathrm{p}$ & $\eta 2$ & \\
\hline \multirow{7}{*}{ Gender } & Science Self-Efficacy & 1 & .323 & .571 & .004 & \multirow{7}{*}{ Girls < boys } \\
\hline & Mathematics Self-Efficacy & 1 & .539 & .465 & .007 & \\
\hline & Self-Concept & 1 & 5.641 & $.020^{*}$ & .064 & \\
\hline & Masculinity & 1 & 1.222 & .272 & .015 & \\
\hline & Femininity & 1 & 1.808 & .182 & .022 & \\
\hline & Machismo & 1 & 1.316 & .255 & .016 & \\
\hline & Submission & 1 & .344 & .559 & .004 & \\
\hline \multirow{7}{*}{$\begin{array}{l}\text { Enrichment Program } \\
\text { Attendance }\end{array}$} & Science Self-Efficacy & 1 & .005 & .944 & .000 & \multirow{7}{*}{$\begin{array}{c}\text { Attends gifted program }<\text { Does } \\
\text { not attend gifted program }\end{array}$} \\
\hline & Mathematics Self-Efficacy & 1 & .286 & .594 & .003 & \\
\hline & Self-concept & 1 & 4.263 & $.042^{*}$ & .049 & \\
\hline & Masculinity & 1 & 2.134 & .148 & .025 & \\
\hline & Femininity & 1 & .351 & .555 & .004 & \\
\hline & Machismo & 1 & 1.470 & .229 & .018 & \\
\hline & Submission & 1 & .262 & .610 & .003 & \\
\hline \multirow{7}{*}{$\begin{array}{l}\text { Gender } x \text { Enrichment } \\
\text { Program Attendance }\end{array}$} & Science Self-Efficacy & 1 & .133 & .716 & .002 & \\
\hline & Mathematics Self-Efficacy & 1 & .206 & .651 & .003 & \\
\hline & Self-Concept & 1 & 2.775 & .100 & .033 & \\
\hline & Masculinity & 1 & 5.479 & $.022^{*}$ & .063 & \\
\hline & Femininity & 1 & .530 & .468 & .006 & \\
\hline & Machismo & 1 & .963 & .329 & .012 & \\
\hline & Submission & 1 & 4.324 & $.041^{*}$ & .050 & \\
\hline
\end{tabular}

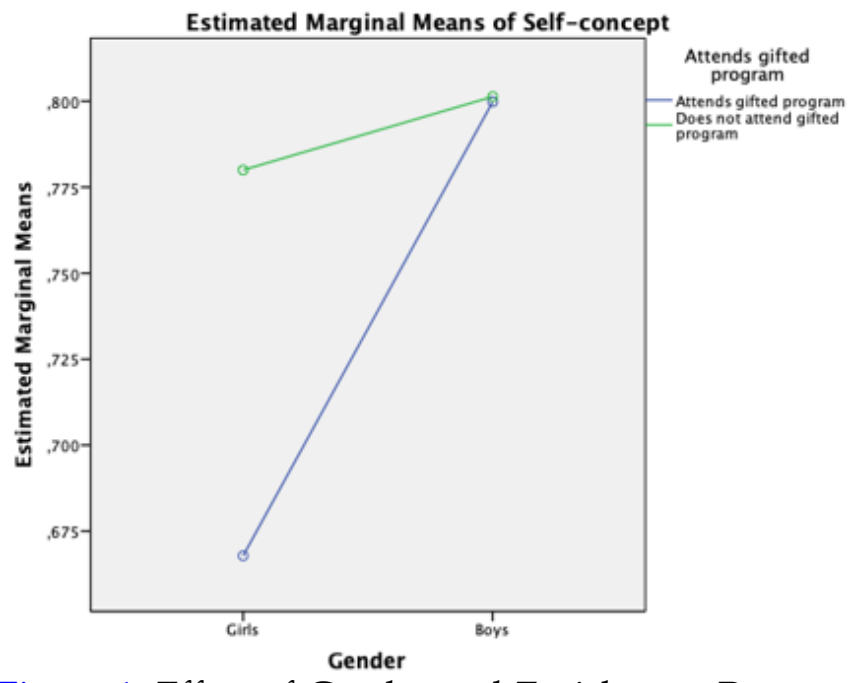

Figure 1. Effect of Gender and Enrichment Program Attendance on Self-Concept

Source. Own elaboration

\section{The Effect of Gender and UBEP Participation on Individual Socioemotional Dimensions}

ANOVAs were run to test the main univariate effects and the interaction of gender and UBEP attendance on individual socioemotional dimensions. The univariate analyses revealed a significant effect of the participants' gender on their self-concept, with higher scores for boys $(M=.78, S D=.11)$ than for girls $(M=.72, S D=.17)$ (see Table 4). A significant effect of gender on the other dependent variables (self-efficacy in science, self-efficacy in mathematics, femininity, masculinity, submission, and machismo) was not observed. Figure 1 shows the average scores for self-concept between girls who attended a UBEP and those who did not. By means of a student's t-test for independent samples, self-concept scores for girls who attended UBEPs and girls who did not were compared and a significant difference was found, $t(46)=-2.00, p=.051$; girls who did not attend UBEPs scored higher $(M=.76, S D=.15)$ than those girls who did attend $(M=.67, S D=.17)$. The same analysis was made between boys who attended UBEPs and those who did not; no significant difference for self-concept was found between these two groups (Figure 1).

An interaction effect was observed between the variables of gender and UBEP attendance on the identification with characteristics associated with masculinity (Table 4). 


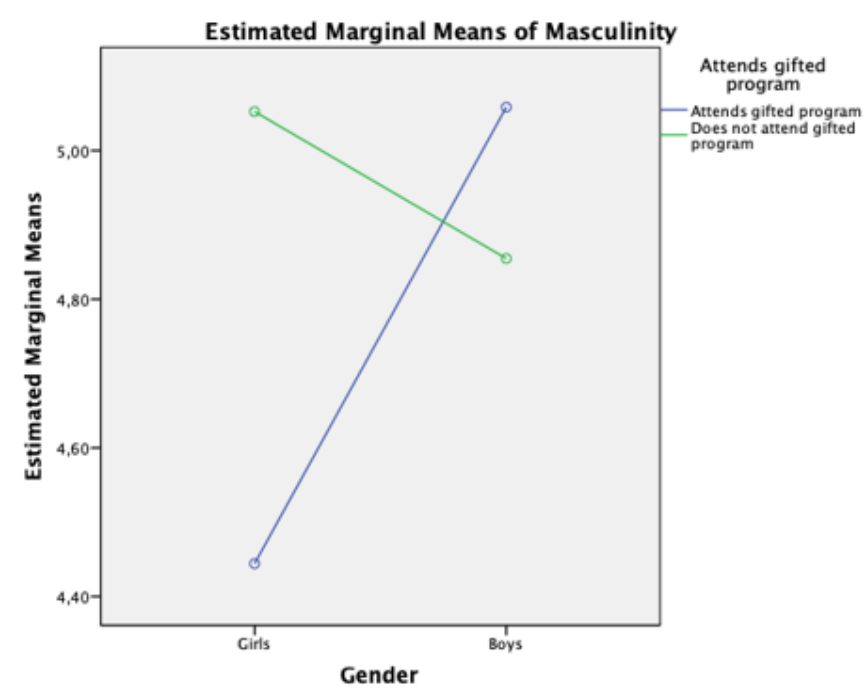

Figure 2. Interaction effect between gender and enrichment program attendance on masculinity Source. Own elaboration

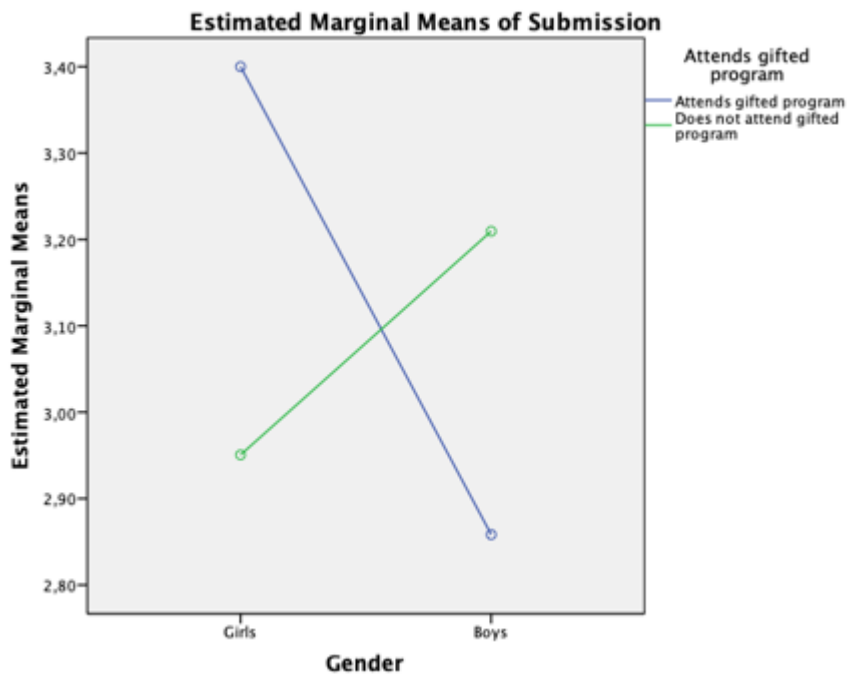

Figure 3. Interaction effect between gender and enrichment program attendance on submission Source. Own elaboration

Girls who attended UBEPs scored lower on masculinity (Figure 2) and higher on submission than girls who did not attend programs (Figure 3). Therefore, by means of a Student's t-test for independent samples, the scores on the masculinity subscale were compared between girls who attended UBEPs and those who did not. Findings indicate that there is a significant difference $t(44)=-2.56, p=.014$, favoring girls that did not attend UBEPs $(M=5.08, S D=.94)$ over girls who did attend UBEPs $(M=4.44, S D=.74)$. No significant differences were observed between boys who attended UBEPs and those who did not on the masculinity subscale (see Figure 2).

Similarly, using a Student's t-test for independent samples, the scores on the submission sub-scale were compared between girls who attended UBEPs and those who did not, finding a significant difference $t(44)=2.07$, $p=.044$, with girls who attended UBEPs scoring higher for negative femininity $(M=3.40, S D=.72)$ than girls who did not attend UBEPs $(M=2.91, S D=.87)$. No significant differences were observed between boys who attended UBEPs and those who did not on the masculinity subscale (see Figure 3).

\section{DISCUSSION}

\section{Self-concept}

The current comparative study contributes to the recent discussions about adolescent gifted girls and the gender gap in education, particularly in STEM fields. The results suggest that for this sample of the population, levels of self-concept and characteristics of gender stereotypes vary by gender and UBEP attendance. Specifically, the results indicated that adolescent gifted female students: (a) had lower selfconcepts than males and (b) girls who attended an UBEP had lower self-concepts than girls who did not participate in these programs.

One plausible explanation for the lower results found in self-concept for girls is that adolescent gifted females experience the BFLPE effect more acutely (Plieninger \& Dickhäuser, 2015) in Chilean culture, which traditionally has different expectations for males and females regarding their abilities and is less supportive of gender equality (Charlin et al., 2016). This phenomenon may be especially intense for adolescent girls in UBEPs who are challenging the more traditional Chilean view of adolescent females by participating in these academic programs. Given that gifted programs are scarce in the country and they involve a highly selective entrance process, adolescent students may feel that they represent their schools and that they must behave in certain ways and demonstrate outstanding academic achievements. In these cases, grades come to represent the maximum expected achievement, especially in a culture that privileges results over the learning process or even personal development (Conejeros et al., 2011).

\section{Self-efficacy}

Regarding self-efficacy, no differences were found in terms of gender and program participation. These results support previous findings for boys and girls in the general population (Probst, 2019) and are in line with findings that show no gender differences in self-efficacy between adolescent gifted males and females (Al-alusi, 2001; Al-Dhaimat et al., 2020; Ayotola \& Adedeji, 2009; Turki \& Al-Qaisi, 2012). These findings could be explained by the fact that these adolescents were selected based on giftedness and positive attitudes toward science and mathematics, which have been found to correlate with self-efficacy (Kundu \& Ghose, 2016). 


\section{Stereotypes}

In comparison with adolescent female participants who did not attend an UBEP, female participants who did attend were found to identify more with characteristics associated with negative femininity, representing submission and indecisiveness, and at the same time they identified less with characteristics of positive masculinity, which represent practicality and action-orientedness. This is in line with findings from previous studies suggesting that adolescent gifted girls may hide attributes that are considered less feminine (Kerr \& Multon, 2015), which means they may also steer towards more traditional careers (Fiebig, 2008). Consequently, these female adolescents could be inclined to over-identify with feminine characteristics typically associated with submission and passivity, fulfilling the stereotyped expectations for women in traditional Chilean culture. Scantebury and Baker (2007) suggest that these gender stereotypes, based on sociocultural patterns that associate masculinity with mathematics and science, and femininity with the humanities, are particularly strong in Latin America, which is congruent with the present results. In relation to these results, although it was not considered a variable in this study, socioeconomic status could also play an important role in gender stereotypes, considering, for example, that in Chile, mid-low socioeconomic groups have been found to associate math with masculinity (Del Río et al. 2016). This finding could be further investigated in subsequent studies in the field.

Also, the profile of adolescent female students who are part of an UBEP could lead to the experience of stereotype threat; living with the label of being gifted and regularly attending an UBEP, a distinctive characteristic compared to the other female participants in the sample, could heighten their perception of risk when falling into categories socio-culturally presumed to be less feminine, or of being "masculinized." This stereotype threat may be a factor as long as success, talent, and competition are associated more with masculinity, particularly in the areas of mathematics and science (Leslie et al., 2015).

Moreover, Deemer et al. (2014) suggested that individuals who are more concerned with achievement outcomes might experience or respond more intensely to gender stereotypes. Therefore, adolescent females who attend UBEPs could worry excessively about not meeting expectations and not living up to their reputation as gifted females. Also, they could face expectations in their immediate environment with higher levels of pressure. Finally, these phenomena could be reinforced by the small gender proportions of females in STEM related classes. Preckel, Zeidner, et al. (2008) indicate that the unbalanced gender rate may lead to a belief in the minority status of females in UBEP classes, which could be interpreted by women as an indication that these classes are more suitable for men. Although this variable was not addressed in the current study, it could be seen as relevant to enrich discussion in future research.

\section{CONCLUSION, LIMITATIONS, AND RECOMMENDATIONS}

This study contributes by describing socio-emotional dimensions (self-concept, self-efficacy, and gender stereotypes) in academically gifted students in Chile that could relate to their interests in STEM areas throughout adolescence. Two practical considerations based on these results are the following:

(1) If gifted adolescent girls who participate in STEM programs over-identify with negative feminine attributes and distance themselves from positive masculine characteristics, they may distance themselves from STEM-oriented careers, which tend to be associated with attributes like action and leadership.

(2) Lower self-concept in gifted adolescent girls (compared to those who did not attend programs) can be taken into account in the design of university-based enrichment programs for gifted students to analyze possible influencing factors. If stereotype threat is a concern, programs could implement grouping strategies, for example in group work to make sure girls are not a minority and incorporate a balanced gender focus, where possible, in their courses. Programs could also be developed to focus on female participants' self awareness, to help them incorporate their talents, interests, and gender identity in a positive way.

There are limitations to acknowledge in this study that open opportunities to explore in further depth in future research. One of these is the lack of information concerning the length of time students have participated in their enrichment programs and other concrete situations (course selection, internal course dynamics, instructional processes, among others) that may offer more insight into other determining factors related to self-concept, which the research has indicated, tends to decrease at the beginning of program participation, but then stabilizes afterwards (Cunningham \& Rinn, 2007).

Two possible methodological limitations must be mentioned: 1) the sample size analyzed and 2) the inclusion of SES in the model. Concerning the sample size, some of the groups analyzed had a small $n$, for example, women who attended UBEPs $(n=17)$. This can be explained by the existence of few UBEPs in Chile and also because the women who attend these programs may not be interested in the areas of math and science. One recommendation for future studies is to increase the sample size, if possible, by involving more of these programs. Regarding the second limitation, the present study did not consider SES as a possible explanatory 
variable in analyzing the variation in these results. In future research, incorporating or controlling for this variable would be recommended.

All of these factors help to frame future research that could enable analysis of the present findings in greater depth, particularly in relation to enrichment program participation where these characteristics appear or tend to intensify. Moreover, the age of these participants indicate a need for longitudinal studies that could trace students' developmental trajectories; cross-cultural studies to compare these constructs between different cultures; and a qualitative approach to further explore students' perceptions, feelings, and inner complexities in the configuration of orientations toward STEM areas that could be relevant in future career choices.

\section{ACKNOWLEDGEMENTS}

We gratefully acknowledge the National Agency of Research and Development (ANID) under the Fondecyt Regular grant 1181770.

\section{REFERENCES}

Agencia Calidad de la Educación (2015). Informe Resultados PISA 2015 [PISA 2015 Results Report]. http:/ / archivos.agenciaeducacion.cl/INFORME_ DE_RESULTADOS_PISA_2015.pdf

Al-Alusi, A. (2001). Self-efficacy and its relationship to selfesteem among university students [Master's thesis, University of Baghdad].

Al-Dhaimat, Y., Albdour, N. T., \& Alshraideh, M. (2020). Creative Self-Efficacy and Its' Relationship to Intellectual Stress among Gifted Students at the Jubilee School. World Journal of Education, 10(3), 208219. https:// doi.org/10.5430/wje.v10n3p208

Ayotola, A., \& Adedeji, T. (2009). The relationship between mathematics self-efficacy and achievement in mathematics. Procedia-Social and Behavioral Sciences, 1(1), 953-957. https:/ / doi.org/10.1016/j.sbspro.2009.01.169

Bandura, A. (1997). Self-efficacy: The exercise of control. Worth Publishers.

Boston, J., \& Cimpian, A. (2018). How Do We Encourage Gifted Girls to Pursue and Succeed in Science and Engineering?. Gifted Child Today, 41(4), 196-207 https:/ / doi.org/10.1177/1076217518786955

Camci-Erdogan, S., \& Riga, F. (2016). Gifted females in science. In K. Taber \& M. Sumida (Eds.). International Perspectives on Science Education for the Gifted: Key Issues and Challenges (pp. 106-125). Routledge. https:/ / doi.org/10.4324/9781315814247

Charles, M. (2017). Venus, Mars, and math: Gender, societal affluence, and eighth graders' aspirations for STEM. Socius: Sociological Research for a Dynamic
World, 3, 1-16. https://doi.org/10.1177/ 2378023117697179

Charlin, V., Torres, A., \& Cayumán, C. (2016). Expectativas de género y logro de estudiantes en TERCE [Gender and Student Achievement Expectations in TERCE]. Midevidencias, 9, 1-8. https:/ / www.mideuc.cl/wpcontent/ uploads/2016/MidEvidencias-N9.pdf

Colangelo, N., \& Assouline, S. G. (1995). Self-concept of gifted students: Patterns by self-concept domain, grade level, and gender. In M. W. Katzko \& F. J. Mönks (Eds.) Nurturing talent: individual needs and social ability (pp. 66-74). Van Gorcum.

Comisión Nacional de Investigación Científica y Tecnológica (2015). Participación Femenina en Programas de CONICYT 2001-2014 [Female Participation in CONICYT Programs 2001-2014]. Santiago, Chile. http://www.conicyt.cl/wpcontent/uploads/2015/03/Participaci \% C3\% B3nFemenina-2014_v5.pdf

Conejeros-Solar, M. L., \& Gómez-Arízaga, M. P. (2015). Gifted students' characteristics, persistence, and difficulties in college. Roeper Review, 37(4), 241-251. https:/ / doi.org/10.1080/02783193.2015.1077909

Conejeros-Solar, M. L., Cáceres, P., \& Oneto, P. (2011). La Desatención Educativa Diferencial: Consecuencias socio-emocionales en Adolescentes con Altas Capacidades [Differential Educational Inattention: Socio-emotional Consequences in Adolescents with High Abilities]. Fondo de Investigación y Desarrollo En Educación [Fund for Research and Development in Education] - FONIDE NoF410983-2009. https: / / centroestudios.mineduc.cl/wpcontent/uploads/sites/100/2017/07/ Informe_Final-UCV-Maria-Leonor-Conejeros.pdf

Conejeros-Solar, M. L., Cáceres, P., \& Riveros, A. M. (2012). Educación de Talentos Académicos en Chile: Una década de aprendizajes e investigación [Education of Academic Talents in Chile: A decade of learning and research]. In J. Catalán (Editor). Investigación orientada al cambio en psicología educacional [Change-oriented research in educational psychology] (pp. 39-74). Editorial Universidad de La Serena.

Cunningham, L. G., \& Rinn, A. N. (2007). The Role of Gender and Previous Participation in a Summer Program on Gifted Adolescents' Self-Concepts over Time. Journal for the Education of the Gifted, 30(3), 326-352.

https: / / doi.org/10.1177/016235320703000303

Dai, D. Y. (2002). Are Gifted Girls Motivationally Disadvantaged? Review, Reflection, and Redirection. Journal for the Education of the Gifted, 25(4), 315-358. https://doi.org/10.4219/jeg-2002283 
Deemer E. D., Thoman D. B., Chase J. P., \& Smith J. L. (2014). Feeling the threat: Stereotype threat as a contextual barrier to women's science career choice intentions. Journal of Career Development, 41(2), 141158. https:/ / doi.org/10.1177/0894845313483003

Del Río, M. F., Strasser, K., \& Susperreguy, M. I. (2016). ¿Son las habilidades matemáticas un asunto de género?: Los estereotipos de género acerca de las matemáticas en niños y niñas de Kínder, sus familias y educadoras [Are math skills a gender issue?: Gender stereotypes about math in kindergarten boys and girls, their families and educators]. Calidad en la Educación-Quality in Education, (45), 20-53. https://doi.org/10.4067/ s0718-45652016000200002

Eccles, J. S. (2013). Gender and achievement choices. In E. T. Gershoff, R. S. Mistry, \& D. Crosby (Eds.), Societal contexts of child development: pathways of influence and implications for practice and policy (pp. 19-34). Oxford University Press. https://doi.org/ 10.1093/acprof:oso/9780199943913.003.0002

Ellemers, N. (2018). Gender Stereotypes. Annual Review of Psychology, 69, 275-298. https:/ / doi.org/10.1146/ annurev-psych-122216-011719

Fiebig, J. N. (2008). Gifted American and German adolescent women: a longitudinal examination of attachment, separation, gender roles, and career aspirations. High Ability Studies 19(1), 67-81. https: / / doi.org/10.1080/13598130801980349

Fiebig, J. N., \& Beauregard, E. (2011). Longitudinal Change and Maternal Influence on Occupational Aspirations of Gifted Female American and German Adolescents. Journal for the Education of the Gifted, 34(1), 45-67. https://doi.org/10.1177/ 016235321003400103

Finch, H. (2005). Comparison of the Performance of Nonparametric and Parametric MANOVA Test Statistics when Assumptions Are Violated. Methodology: European Journal of Research Methods for the Behavioral and Social Sciences, 1(1), 27-38. https:/ / doi.org/10.1027/1614-1881.1.1.27

Fraser, B. (1981). Test of Science-Related Attitudes [Handbook]. Allanby Press, Macquarie University.

Gagné, F. (2015). De los genes al talento: La perspectiva DMGT/CMTD. Revista de Educación, 368, 12-39. https: / / doi.org/10.4438/1988-592X-RE-2015-368289

Gagné, F. (2018). Academic talent development: Theory and best practices. In S. I. Pfeiffer (Ed.), APA Handbook of Giftedness and Talent (pp. 163-184). American Psychological Association. https:/ / doi.org/10.1037/0000038-011

Gómez-Arízaga, M., \& Conejeros-Solar, M.L. (2013). Am I That Talented? The experiences of gifted individuals from diverse educational backgrounds at the postsecondary level. High Ability Studies. 24(2), 135-151. https://doi.org/10.1080/13598139. 2013.838898

Gómez-Arízaga, M., Valdivia-Lefort, M., CastilloHermosilla, H., Hébert, T., \& Conejeros-Solar, M. (2020). Tales from Within: Gifted Students' Lived Experiences with Teaching Practices in Regular Classrooms. Education Sciences. 10(5), 137. https:/ / doi.org/10.3390/educsci10050137

Greenlee M. (2016). The Effects of Girls self-efficacy on their Interest and Involvement in Mathematics and Science. (Master's thesis), California State University. http:/ / dspace.calstate.edu/bitstream/handle/102 11.3/163467/Greenlee-Mary-thesis2016.pdf?sequence $=1$

Gubbels J., Segers, E., \& Verhoeven, L. (2014). Cognitive, socioemotional, and attitudinal effects of a triarchic enrichment program for gifted children. Journal for the Education of the Gifted, 37, 378-397. https:/ / doi.org/10.1177/0162353214552565

Hattie, J. A. C. (2009). Visible learning: A synthesis of over 800 meta-analyses relating to achievement. Routledge. https:/ / doi.org/10.4324/9780203887332

Heilbronner, N. N. (2013). The STEM Pathway for Women: What Has Changed? Gifted Child Quarterly, 57(1), 39-55. https://doi.org/10.1177/0016986212 460085

Huang, C. (2011). Self-concept and academic achievement: A meta-analysis of longitudinal relations. Journal of School Psychology, 49(5), 505-528. https:// doi.org/10.1016/j.jsp.2011.07.001

Hutchinson, J. (2013). School Organisation and STEM Career related Learning. STEM Centre, University of Derby. https:/ / core.ac.uk/download/pdf/46170662.pdf

Kao, C. (2015). Mathematically gifted adolescent females' mixed sentiment toward gender stereotypes. Social Psychology of Education, 18(1), 1735. https:/ / doi.org/10.1007/s11218-014-9278-2

Kaufman, S. B., \& Sternberg, R.J. (2008). Conceptions of Giftedness. In S. I. Pfeiffer (Ed.) Handbook of Giftedness in Children (pp. 71-91). Springer. https: / / doi.org/10.1007/978-0-387-74401-8_5

Kerr, B. (Ed.). (2009). Encyclopedia of giftedness, creativity and talent. SAGE. https://doi.org/10.4135/ 9781412971959

Kerr, B. A., \& Kurpius, S. (2004). Encouraging talented girls in math and science: Effects of a guidance intervention. High Ability Studies, 15(1), 85-102. https:/ / doi.org/10.1080/1359813042000225357

Kerr, B. A., \& McKay, R. (2014). Smart Girls in the 21st Century: Understanding Talented Girls and Women. Great Potential Press, Inc. 
Kerr, B. A., \& Multon, K. D. (2015). The development of gender identity, gender roles, and gender relations in gifted students. Journal of Counseling $\mathcal{E}$ Development, 93, 183-191. https:/ / doi.org/10.1002/ j.1556-6676.2015.00194.x

Kerr, B. A., Vuyk, M. A., \& Rea, C. (2012). Gendered practices in the education of gifted girls and boys. Psychology in the Schools, 49(7), 647-655. https://doi.org/10.1002/pits.21627

Kollmayer, M., Schober, B., \& Spiel, C. (2016). Gender stereotypes in education: Development, consequences, and interventions. European Journal of Developmental Psychology, 15(4), 361-377. https:/ / doi.org/10.1080/17405629.2016.1193483

Kundu, A., \& Ghose, A. (2016). The relationship between attitude and self-efficacy in mathematics among higher secondary students. Journal of Humanities and Social Science, 21(4), 25-31. http:/ / iosrjournals. org/iosr-jhss / papers/Vol.\%2021\%20Issue4/ Version-5/F0214052531.pdf

Lee, C. Y., \& Kung, H. Y. (2018). Math self-concept and mathematics achievement: Examining gender variation and reciprocal relations among junior high school students in Taiwan. Eurasia Journal of Mathematics, Science and Technology Education, 14(4), 1239-1252.

https:// doi.org/10.29333/ ejmste/82535

Leslie, S. J., Cimpian, A., Meyer, M., \& Freeland, E. (2015). Expectations of brilliance underlie gender distributions across academic disciplines. Science, 347(6219), 262-265. https://doi.org/10.1126/ science. 1261375

Lewis, J. D., \& Knight, H. V. (2000). Self-concept in gifted youth: An investigation employing the Piers-Harris subscales. Gifted Child Quarterly, 44, 45-53. https:/ / doi.org/10.1177/001698620004400105

López, V., Conejeros, M. L., García, M. C., Gudenschwager, H., \& Proestakis, A. (2013). Gifted Education in Chile amidst Public Debate on Excellence without Equity in Education. In P. Sanchez-Escobedo. Talent development around the world. A global perspective on gifted education (pp.167199). Lambert Academic Publishing.

Mackintosh, N. J., \& Bennett, E. S. (2005). What do Raven's Matrices measure? An analysis in terms of sex differences. Intelligence, 33, 663-674. https://doi.org/10.1016/j.intell.2005.03.004

Martínez-Gómez, J., Guerrero-Rodríguez, S. M., \& ReyAnacona, C. A. (2012). Evaluación de la validez de constructo y la confiabilidad del inventario de masculinidad y femineidad en adolescentes y adultos jóvenes colombianos [Evaluation of the construct validity and reliability of the inventory of masculinity and femininity in Colombian adolescents and young adults]. Avances en Psicología
Latinoamericana-Advances in Latin American Psychology, 30(1), 170-181. https:/ / revistas.urosario. edu.co/index.php/apl/article/view/1180/1800

Maso, V. \& Proestakis, A. (2007). Talento y Género: Reconstrucción de la experiencia de adolescentes mujeres de 13 a 17 años con Talento Académico que asisten al Programa DeLTA UCN [Talent and Gender: Reconstruction of the experience of adolescent women between the ages of 13 and 17 with academic talent who attend the DeLTA UCN Programme]. Boletin de Educación, Universidad Católica del Norte, 39, 1-28. https://www. researchgate.net/profile/Verena_Maso_Varas/pu blication/258499233_Talento_y_Genero_Reconstr uccion_de_la_experiencia_de_adolescentes_mujer es_de_13_a_17_anos_con_Talento_Academico_qu e_asisten_al_Programa_DeLTA_UCN/links/00b4 952857e55b681a000000.pdf

Microsoft Foundation (2016). Why Europe's girls aren't studying STEM. https://news.microsoft.com/ europe/features/dont-european-girls-like-sciencetechnology/\#sm.00001s38on4s1 eopuj124aj97v6kn

Miller, D. I., Eagly, A. H., \& Linn, M. C. (2015). Women's representation in science predicts national genderscience stereotypes: Evidence from 66 nations. Journal of Educational Psychology, 107(3), 631-644. https:/ / doi.org/10.1037/edu0000005

Ministerio de Educación (2010). Decreto 341. Modifica decreto $n^{\circ}$ 230, de 2007, que establece normas que regulan el programa promoción de talentos en escuelas y liceos y fija texto refundido [Decree 341. Modifies Decree No. 230, of 2007, which establishes norms that regulate the talent promotion program in schools and high schools and establishes a consolidated text]. http:/ /legislacion-oficial.vlex.cl/vid/modificatalentos-liceos-refundido-240277002

Ministerio de Educación. (2011). Becas y créditos educación superior. Beca de Nivelación Académica (propedéutico) [Scholarships and financial aid in higher education: Scholarship for academic remedial]. http://portal2010.becasycreditos.cl/ beca_propedeutico.html

Nagy, G., Watt, H. M. G., Eccles, J., Trautwein, U., Lüdtke, O., \& Baumert, J. (2010). The development of students' mathematics self-concept in relation to gender: Different countries, different trajectories? Journal of Research on Adolescence, 20, 482-506. https:/ / doi.org/10.1111/j.1532-7795.2010.00644.x

National Association for Gifted Children (2020, June 15). What is Giftedness? https:/ / www.nagc.org/

Navarro, M., Förster, C., González, C., \& González-Pose, P. (2016). Attitudes toward science: Measurement and psychometric properties of the test of sciencerelated attitudes for its use in Spanish-speaking classrooms. International Journal of Science Education, 
38(9), 1459-1482. https://doi.org/10.1080/ 09500693.2016.1195521

Neber, H., \& Schommer-Aikins, M. (2002). Self-regulated science learning with highly gifted students: The role of cognitive, motivational, epistemological, and environmental variables. High ability studies, 13(1), 59-74. https:/ / doi.org/10.1080/13598130220 132316

Ogbuehi, P. I., \& Fraser, B. J. (2007). Learning environment, attitudes and conceptual development associated with innovative strategies in middle-school mathematics. Learning Environments Research, 10(2), 101-114. https:/ / doi.org/10.1007/s10984-007-9026-z

Olson, C. L. (1979). Practical considerations in choosing a MANOVA test statistic: A rejoinder to Stevens. Psychological Bulletin, 86(6), 1350-1352. https:/ / doi.org/10.1037/0033-2909.86.6.1350

Organisation for Economic Co-operation and Development (2008). Informe PISA 2006, Competencias científicas para el mundo del mañana [PISA 2006 Report, Scientific Competences for Tomorrow's World]. Santillana.

Organisation for Economic Co-operation and Development (2014). PISA 2012 Results: What Students Know and Can Do - Student Performance in Mathematics, Reading and Science. OECD Publishing, 1. https://doi.org/10.1787/19963777

Organisation for Economic Co-operation and Development (2015). The ABC of Gender Equality in Education: Aptitude, Behaviour, Confidence. OECD Publishing. https:// doi.org/10.1787/978926 4229945-en

Osandón, L., Caro, M., Magendzo, A., Abraham, M., Lavín, S., González, F., \& Cabaluz, J. F. (2018). Estado, mercado y currículum escolar: la experiencia chilena (1964-2018) [State, market and school curriculum: the Chilean experience (19642018)]. Reflexiones en curso, $N^{\circ} 20$, Serie Cuestiones actuales y fundamentales del currículo, el aprendizaje y la evaluación [Ongoing Reflections, No. 20, Current and Fundamental Issues of Curriculum, Learning and Assessment Series]. IBE-UNESCO. https://www. researchgate.net/publication/326424061_Osandon _et_al_2018_Estado_mercado_y_curriculum_escol ar_la_experiencia_chilena_1964-2018_Reflexiones_ en_curso_N_20_Serie_Cuestiones_actuales_y_fun damentales_del_curriculo_el_aprendizaje_y_la_ev aluacion? channel $=$ doi\&linkId $=5 b 4 c c 2 c 50 f 7 e 9 b 240 f$ e4eb2c\&showFulltext=true

Pajares, F., \& Graham, L. (1999). Self-efficacy, motivation constructs, and mathematics performance of entering middle school students. Contemporary educational psychology, 24(2), 124-139. https:// doi.org/10.1006/ceps.1998.0991
Parker, P. D., Marsh, H. W., Ciarrochi, J., Marshall, S., \& Abduljabbar, A. S. (2014). Juxtaposing math selfefficacy and self-concept as predictors of long-term achievement outcomes. Educational Psychology, 34, 29-48.

https:// doi.org/10.1080/01443410.2013.797339

Peer, J., \& Fraser, B. (2015). Sex, grade-level and stream differences in learning environment and attitudes to science in Singapore primary schools. Learning Environments Research, 18(1), 143-16. https://doi.org/10.1007/s10984-013-9142-x

Plieninger, H., \& Dickhäuser, O. (2015). The female fish is more responsive: gender moderates the bflpe in the domain of science. Educational Psychology, 35, 213-227.

https:// doi.org/10.1080/01443410.2013.814197

Preckel, F., Goetz, T., Pekrun, R., \& Kleine, M. (2008). Gender differences in gifted and average ability students. Gifted Child Quarterly, 52, 146-159. https:/ / doi.org/10.1177/0016986208315834

Preckel, F., Zeidner, M., Goetz, T., \& Schleyer, E. J. (2008). Female 'big fish' swimming against the tide: the 'big-fish-little-pond effect' and gender-ratio in special gifted classes. Contemporary Education Psychology, 33(1), 78-96. https://doi.org/10.1016/ j.cedpsych.2006.08.001

Probst, J. R. (2019). A Causal-Comparative Analysis of Mathematics Self-Efficacy Based on Gender and Math Acceleration (Doctoral dissertation), Liberty University.

https://core.ac.uk/download/pdf/213463554.pdf

Raven, J., Raven, J. C., \& Court, J. H. (1993). Test de Matrices Progresivas (Manual). Paidós.

Recber, S., Isiksal, M., \& Koç, Y. (2018). Investigating selfefficacy, anxiety, attitudes and mathematics achievement regarding gender and school type. Anales de Psicología/Annals of Psychology, 34(1), 4151. https:/ / doi.org/10.6018/analesps.34.1.229571

Reilly, D., Neumann, D., \& Andrews, G. (2019). Investigating Gender Differences in Mathematics and Science: Results from the 2011 Trends in Mathematics and Science Survey. Research in science education, 49, 25-50. https://doi.org/10.1007/ s11165-017-9630-6

Roa-Tampe, K., Castillo-Hermosilla, H., Valdivia-Lefort, M., Briseño Ossandon, M., Gómez-Arízaga, M., Navarro, M., Martin, A., Rivera-Lino, B., \& Conejeros-Solar, M. (2020). Autoconcepto y alta capacidad: influencia de estereotipos de género y programas de enriquecimiento [Self-concept and high ability: influence of gender stereotypes and enrichment programs]. Revista Espacios, 41(17). https://www.revistaespacios.com/a20v41n17/20 411714.html 
Rudasill, K. M., Capper, M. R., Foust, R. C., Callahan, C. M., \& Albaugh, S. B. (2009). Grade and Gender Differences in Gifted Students' Self-Concepts. Journal for the Education of the Gifted, 32(3), 340-367. https:// doi.org/10.4219/jeg-2009-862

Scantebury, K., \& Baker, D. (2007). Gender issues in science education research: Remembering where the differences lie. In S. Abell \& N. Lederman (Eds.), Handbook of Research on science education (pp. 257-286). Lawrence Erlbaum. https://www. researchgate.net/publication/274523811_Compar ative_Study_on_Pre-Service_Science

_Teachers'_Self-Efficacy_Beliefs_of_Teaching_in Kenya_and_the_United_States_of_America_USA

Schunk, D. H., \& DiBenedetto, M. K. (2016). Self-Efficacy Theory in Education. In K. R. Wentzel \& David B. (Eds.), Handbook of Motivation at School (pp. 34-54). Routledge Handbooks Online. https://www. routledgehandbooks.com/doi/10.4324/978131577 3384.ch3

Steele, C. M. (1997). A threat in the air: How stereotypes shape intellectual identity and performance. American Psychologist, 52(6), 613-629. https:/ / doi.org/10.1037/0003-066X.52.6.613

Turki, J., \& Al-Qaisi, L. (2012). Adjustment problems and self-efficacy among gifted students in Salt Pioneer Center. Int J EduSci, 4(1), 1-6. https:/ / doi.org/10.1080/09751122.2012.11890020

Usher, E. L., \& Pajares, F. (2009). Sources of self-efficacy in mathematics: A validation study. Contemporary Educational Psychology, 34(1), 89-101. https://doi.org/10.1016/j.cedpsych.2008.09.002

Valenti, S., Masnick, A., Cox, B., \& Osman, C. (2016). Adolescents' and Emerging Adults' Implicit Attitudes about STEM Careers: "Science Is Not Creative". Science Education International, 27(1), 4058.
Vera, A., Castejón, J., Miñano, P., \& Gilar-Corbí, R. (2019). Actitudes en la adolescencia inicial y rendimiento académico: el rol mediacional del autoconcepto académico [Attitudes in early adolescence and academic performance: the mediating role of academic self-concept]. Revista de Psicodidáctica, 24(1), 71-77. https:/ / doi.org/10.1016 /j.psicoe.2018.11.002

Villarroel, V. (2001). Relación entre autoconcepto y rendimiento académico [Relationship between selfconcept and academic performance]. PSYKHE, 10(1), 3-18. http://www.psykhe.cl/index.php/ psykhe/article/view/418

Webb-Williams, J. (2018). Science self-efficacy in the primary classroom: Using mixed methods to investigate sources of self-efficacy. Research in Science Education, 48(5), 939-961. https: / / doi.org/10.1007/s11165-016-9592-0

Young, J. L., Young, J. R., \& Ford, D. Y. (2019) Culturally Relevant STEM Out-of-School Time: A Rationale to Support Gifted Girls of Color, Roeper Review, 41(1), 8-19. https: / / doi.org/10.1080/02783193.2018.1553215

Zalazar, M. F., Aparicio, M. M. D., Ramírez, C. M., \& Garrido, S. J. (2011). Estudios Preliminares de Adaptación de la Escala de Fuentes de Autoeficacia para Matemáticas [Preliminary Studies of Adaptation of the Scale of Sources of Self-efficacy for Mathematics]. Revista Argentina de Ciencias del Comportamiento, 3(2), 1-6. http:/ / www.redalyc.org / articulo.oa?id=333427073001

Zohar, A., \& Sela, D. (2003). Her physics, his physics: Gender issues in Israeli advanced placement physics classes, International Journal of Science Education, 25(2), 245-268. https:/ / doi.org/10.1080/ 09500690210126766

\section{http://www.ejmste.com}

